Article

\title{
Susceptibility to Degradation, the Causes of Degradation, and Trophic State of Three Lakes in North-West Poland
}

\author{
Agnieszka Tórz, Małgorzata Bonisławska *, Agnieszka Rybczyk, Arkadiusz Nędzarek (D) and \\ Adam Tański \\ West Pomeranian University of Technology in Szczecin, Faculty of Food Sciences and Fisheries, K. Królewicza 4, \\ 71-550 Szczecin, Poland; atorz@zut.edu.pl (A.T.); arybczyk@zut.edu.pl (A.R.); anedzarek@zut.edu.pl (A.N.); \\ atanski@zut.edu.pl (A.T.) \\ * Correspondence: mbonislawska@zut.edu.pl
}

Received: 19 March 2020; Accepted: 5 June 2020; Published: 7 June 2020

\begin{abstract}
Effective protection of lakes against degradation requires a detailed recognition of the factors leading to their eutrophication. This also pertains to small lakes, which constitute an important element of various ecosystems and are crucial for maintaining biodiversity. Therefore, the aim of the study is to determine the trophic state as well as the susceptibility to degradation of three small lakes in north-western Poland: Maszewo, Starzyca, and Nowogardzkie. This study analyzes the morphometric characteristics of the lakes, the impact of the catchment, their actual trophic state, and phosphorus levels. The analysis showed varying regeneration potentials of the lakes. Maszewo Lake is eutrophic-hypertrophic, nonresilient, strongly exposed to influence from the catchment, with phosphorus levels within the norm. Starzyca Lake is a eutrophic lake, not very resilient to the influence of the catchment, with excessive phosphorus levels. Nowogardzkie Lake is a eutrophic lake with moderate resilience to degradation, but with excessive phosphorus levels, which endangers the functioning of this aquatic ecosystem. In all the lakes, phosphorus supply was predominantly internal. Restoration of these lakes could be performed by completely cutting off the inflow of nutrients, as well as reclamation involving the deactivation of phosphorus (e.g., by precipitation) as well as the removal of the bottom sediments responsible for the internal supply of phosphorus.
\end{abstract}

Keywords: Maszewo; Starzyca; Nowogardzkie lakes; Carlson indices; resilience of lakes to the impact of catchment land management; anthropogenic pressure; trophic state

\section{Introduction}

Surface waters, essential for human life, and used on a massive scale for private and industrial purposes, constitute ecosystems whose self-renewal depends on the cyclic transformation of organic and mineral matter. The condition of these ecosystems is crucial for the preservation of biodiversity [1-3] and hence the significance of human efforts to protect or restore them. Unfortunately, the actual utilization of natural resources contributes to their degradation [4]. Water resources around the world are deteriorating significantly. Poland is one of the European countries where water resources are not among the highest. On average, in Europe, there is about $4500 \mathrm{~m}^{3}$ of water per person annually, while in Poland, it is only about $1800 \mathrm{~m}^{3}$ (average value from 1946-2016) [5,6]. In deficit years, Poland has only slightly over $1100 \mathrm{~m}^{3}$ per person, while in moist years, resources reach $2600 \mathrm{~m}^{3}$ per person (according to CSO 2017 data). The average amount of water per European inhabitant is 2.5 times higher than in Poland, at approximately $4500 \mathrm{~m}^{3}$ per year. 
This requires not only the assessment of the current state of water by monitoring but also the determination of the factors responsible for the observed changes.

Eutrophication, a natural process of enrichment of waters with nutrients, is currently one of the main factors adversely affecting the quality of surface waters. This is due to human activity, which directly or indirectly increases the rate of the eutrophication process and thus disrupts aquatic ecosystems. A particularly important factor here is the quantity of supplied phosphorus, a major factor limiting primary production in water bodies [7-10]. Lakes are a type of surface water characterized by a specific range of tolerance to external factors (both natural and anthropogenic). An imbalance in that ecosystem may lead to the complete degradation of waters, a threat concerning the vast majority of lakes in many European countries. For example, in Poland, elevated concentrations of total phosphorus are the reason for degraded water quality in about $85 \%$ of the lakes, which is similar to the situation reported in Great Britain, Spain, Romania, Denmark, and the Netherlands [1,11-14].

According to Kubiak [15], geochemical investigation of the lakes in the West Pomeranian Voivodeship indicated that a number of lakes should be considered eutrophic. In the 1970s, only 5 reservoirs showed mesotrophy (Miedwie, Morzycko, Krzemień, Ińsko, and Zajezierze lakes), and two lakes (Jelenin and Woświn) remained on the border of b-mesotrophy and eutrophy. Due to the economic changes in Poland after 1990, and then Poland's accession to the European Union, favorable trends were observed in the geochemical conditions of some of the lakes of the West Pomeranian Voivodeship [16]. From 1998-2004, favorable changes occurred in water and sewage management in West Pomerania. Such trends may contribute to further improvement of the hydrochemical conditions of the lakes of this region. Unfortunately, a number of authors undertaking assessments of hydrochemical conditions in lakes, primarily pay attention to those with an area above $0.5 \mathrm{~km}^{2}$ [15], have reported unfavorable climatic and hydrological conditions observed in Poland in recent years, contributing to the reduction of water resources and leading to greater interest in the ecological status of lakes with smaller areas.

In order to effectively protect lakes from degradation, measures should be taken to limit excessive eutrophication. The effectiveness of these actions may be substantially enhanced if the state of eutrophication and the direction of changes in trophic state are known in each body of water. Such a comprehensive assessment of lake ecosystems requires analysis of the relationships and interactions of both biotic and abiotic factors [11,17], allowing a determination of whether changes in water quality are the result of short-term environmental conditions or the result of local conditions connected with the given catchment, or if they reflect the general deterioration of the environment from increased anthropopressure $[18,19]$. The need for a thorough insight into the matter has been addressed by the European Union, which launched programs for the restoration of degraded water ecosystems, often including the analysis of indicators of water eutrophication [20].

Considering the importance of lake waters for the preservation of water resources, this study undertakes a comprehensive diagnosis of three lakes (Maszewo, Starzyca, and Nowogardzkie) located in the West Pomeranian Voivodeship. These lakes were selected for analysis because they have areas below $1.0 \mathrm{~km}^{2}$, a significant level of eutrophication, and an urban location. It is assumed that the presented diagnosis will assist in developing actions that may contribute to improving the condition of the lakes under study, and thus preserving their resources.

\section{Materials and Methods}

\subsection{General Characteristics of the Selected Lakes}

The abiotic typology of surface waters in Poland, according to the requirements of the Water Framework Directive (WFD), was developed by a consortium of four institutes, the Institute of Meteorology and Water Management, the Institute of Environmental Protection, the Polish Geological Institute, and the Maritime Institute on behalf of the Minister of Environment, in the form of the study "Typology of surface waters and designation of surface and groundwater bodies in accordance with 
the requirements of the Water Framework Directive 2000/60/EC" in 2004. In 2014, an update of water body lists was prepared for the next update of plans in the years 2015-2021, along with the verification of water body types, using STAGE I methodology edited by Hobot (ed) [21].

The studies mentioned above show that all the lakes covered by the analysis are part of the Odra river basin, the Lower Odra water region, and the coastal zone. Their detailed locations are Maszewo Lake: $53^{\circ} 30^{\prime} 18.3^{\prime \prime} \mathrm{N}, 1^{\circ} 03^{\prime} 15.2^{\prime \prime}$ E; Starzyca Lake: $53^{\circ} 27^{\prime} 52.4^{\prime \prime} \mathrm{N}, 15^{\circ} 20^{\prime} 01.7^{\prime \prime} \mathrm{E}$; Nowogardzkie Lake: $53^{\circ} 40^{\prime} 04.0^{\prime \prime} \mathrm{N}, 15^{\circ} 06^{\prime} 20.6^{\prime \prime} \mathrm{E}$. The ecological status of the Starzyca and Nowogardzkie lakes has been previously assessed by Hobot (ed) [21] as poor (both eutrophically and hypertrophically), while in terms of risk assessment of non-achievement of environmental goals, they are classified as endangered (Table 1).

Table 1. Characteristics of surface water bodies under analysis.

\begin{tabular}{|c|c|c|c|c|}
\hline Lake & Catchment Basin & Aquatic Region & Ecological Status & $\begin{array}{l}\text { The risk of Failure to Meet } \\
\text { Environmental Objectives }\end{array}$ \\
\hline Maszewo * & Odra & $\begin{array}{l}\text { Lower Odra and } \\
\text { Coastal Zone }\end{array}$ & - & - \\
\hline $\begin{array}{l}\text { Starzyca (Starzyc, } \\
\text { Chociwel) }\end{array}$ & Odra & $\begin{array}{l}\text { Lower Odra and } \\
\text { Coastal Zone }\end{array}$ & poor & high \\
\hline $\begin{array}{l}\text { Nowogardzkie } \\
\text { (Nowogardno) }\end{array}$ & Odra & $\begin{array}{l}\text { Lower Odra and } \\
\text { Coastal Zone }\end{array}$ & poor & high \\
\hline
\end{tabular}

* not listed by Hobot (ed) [21] because of the very small area $<0.50 \mathrm{~km}^{2}$.

The analyzed lakes are morphometrically different, with areas ranging from 0.128 to $0.983 \mathrm{~km}^{2}$. Therefore, according to the WFD, these are medium and small lakes. In terms of their average depth, they are shallow (Nowogardzkie Lake) and very shallow (Maszewo and Starzyca lakes) (Table 2).

Table 2. Morphometric data of the studied lakes.

\begin{tabular}{lcccc}
\hline \multicolumn{1}{c}{ Parameter } & Unit & Maszewo & Starzyca & Nowogardzkie \\
\hline Surface area & $\left(\mathrm{km}^{2}\right)$ & 0.128 & 0.592 & 0.983 \\
Water volume & $\left(10^{3} \mathrm{~m}^{3}\right)$ & 264.0 & 1575.8 & 5087.3 \\
Maximum depth & $(\mathrm{m})$ & 3.0 & 6.1 & 10.9 \\
Mean depth & $(\mathrm{m})$ & 2.0 & 2.6 & 5.1 \\
Length & $(\mathrm{m})$ & 1430 & 1960 & 2410 \\
Width & $(\mathrm{m})$ & 150 & 370 & 600 \\
Shoreline length & $(\mathrm{m})$ & 3180 & 5175 & 5700 \\
\hline
\end{tabular}

These lakes have different geochemical characteristics. In Poland, as in many other European countries, the division into eco-regions proposed by Illies [22] and imposed by the WFD in System A does not sufficiently reflect the variability of the country's geographical and natural environment. Therefore, this study additionally used Kondracki's [23] division into physical and geographical regions. Poland is divided into three eco-regions.

In an earlier study (2004), it was assumed that Maszewo Lake belonged to type 3b (lakes with high calcium content and high impact of catchments, non-stratified), Starzyca Lake also to type 3b, and Nowogardzkie Lake to type 3a (lakes with high calcium content and high impact of the catchment, stratified). However, the later study edited by Hobot (ed) [21] classified Nowogardzkie Lake as type 2a (lakes with high calcium content and low impact of the catchment, stratified).

The lakes selected for analysis remain under varying environmental pressure. Starzyca Lake has the smallest catchment area, while Nowogardzkie Lake has the largest (Table 3). A substantial portion of three watersheds is comprised of arable land (between 39\% and 51\%). The highest share of forests are found around the Maszewo Lake catchment area (32\%), while urbanized areas in the catchment areas of the studied lakes are between $17 \%$ and $23 \%$ (Table 3 ). 
Table 3. Structure of the catchments of the lakes under study.

\begin{tabular}{lcccc}
\hline & & Maszewo & Starzyca & Nowogardzkie \\
\hline The catchment: & $\mathrm{km}^{2}$ & 2.32 & 1.75 & 6.33 \\
\hline $\begin{array}{l}\text { Including: } \\
\text { arable land }\end{array}$ & $\%$ & 39 & 49 & 51 \\
forests & $\%$ & 32 & 21 & 17 \\
meadow & $\%$ & 12 & 10 & 9 \\
urban areas & $\%$ & 17 & 20 & 23 \\
\hline
\end{tabular}

\subsection{Analytical Methods}

The research was conducted in the spring-summer period of 2018. Water samples were taken from the surface and bottom layer of Maszewo, Starzyca, and Nowogardzkie lakes.

Temperature was measured directly during water sampling $(\mathrm{pH}$ meter with a thermometer, Elmetron CP-103 Poland). Water from the bottom layers of the lakes was collected using a Ruttner type sampler (3L capacity). Water transparency was recorded using a 30-cm Secchi disc from KC Denmark A/S.

Water quality indicators necessary to determine eutrophication were determined according to the recommendations of the Standard Methods [24] (Table 4).

Table 4. Laboratory methods used to determine the parameters of the lake waters.

\begin{tabular}{lll}
\hline \multicolumn{1}{c}{ Parameter } & Method & Units \\
\hline Temperature & Standard Method 2550 & $\left({ }^{\circ} \mathrm{C}\right)$ \\
Dissolved oxygen (DO) & Standard Method 4500-O B & $\left(\mathrm{mg} \mathrm{O}_{2} \cdot \mathrm{dm}^{-3}\right)$ \\
Total phosphorus (TP) & Standard Method 4500-P & $\left(\mathrm{mg} \mathrm{P} \cdot \mathrm{dm}^{-3}\right)$ \\
Chlorophyll “a" & Standard Method 10200-H & $\left(\mu \mathrm{g} \cdot \mathrm{m}^{-3}\right)$ \\
\hline
\end{tabular}

\subsection{Resilience of the Examined Lakes to the Influence of the Catchment}

The category of lake resilience to the catchment impact was assessed on the basis of the Lake Quality Assessment System (LQAS) [25] in a version modified by Bajkiewicz-Grabowska [1,26-28]. According to this method, points from 0 (high resilience of the lake to the influence of the catchment) to 3 (lack of resilience to the influence of the catchment) are given to particular features (Table 5). The final score is the arithmetic mean of the sum of points obtained from the evaluation of individual characteristics (Table 6). 
Table 5. Criteria for assessing the lake resilience to the influence of the catchment, based on Bajkiewicz-Grabowska [1].

\begin{tabular}{|c|c|c|c|c|}
\hline \multirow{2}{*}{ Parameter } & \multicolumn{4}{|c|}{ Score } \\
\hline & 0 & 1 & 2 & 3 \\
\hline Mean depth [m] (a) & $>10$ & $5-10$ & $3-5$ & $<3$ \\
\hline $\begin{array}{l}\text { Volume of the lake in relation to shoreline length } \\
\left(\mathrm{m}^{3} \cdot \mathrm{m}^{-1}\right)(\mathrm{b})\end{array}$ & $>5$ & $3-5$ & $1-3$ & $<3$ \\
\hline $\begin{array}{l}\text { Percentage of lake stratification during summer } \\
\text { stagnation }(\%)(\mathrm{c})\end{array}$ & $>35$ & $20-35$ & $10-20$ & $<10$ \\
\hline $\begin{array}{l}\text { Surface area of the active bottom in relation to } \\
\text { epilimnion volume }\left(\mathrm{m}^{2} \cdot \mathrm{m}^{-3}\right)(\mathrm{d})\end{array}$ & $<0.10$ & $0.10-0.15$ & $0.15-0.30$ & $>0.30$ \\
\hline $\begin{array}{l}\text { Schindler's coefficient-quotient of total catchment to } \\
\text { lake capacity }\left(\mathrm{m}^{2} \cdot \mathrm{m}^{-3}\right)(\mathrm{e})\end{array}$ & $<10$ & $10-30$ & $30-100$ & $>100$ \\
\hline
\end{tabular}

Table 6. Categories of lake resilience to the impact of the catchment, based on Bajkiewicz-Grabowska [1].

\begin{tabular}{clc}
\hline Final Score & Descriptive Characteristics of the Lake & Lake Resilience Category \\
\hline$\leq 0.89$ & High resilience of the lake to catchment impact & Category I \\
$0.90-1.69$ & Moderate resilience of the lake to catchment impact & Category II \\
$1.70-2.40$ & Low resilience of the lake to catchment impact & Category III \\
$\geq 2.41$ & A nonresilient lake, strongly vulnerable to the catchment impact & Category IV \\
\hline
\end{tabular}

\subsection{Evaluation of Anthropogenic Pressure on the Lakes under Study}

Anthropogenic pressure was assessed using mathematical models adopted from Vollenweider [29-32], which allowed the modeling of any parameter (e.g., phosphorus circulation) without analyzing in detail the processes taking place within the system. In his models, Vollenweider includes lakes with low or very low internal supply, and the model can be used for lakes with higher internal supply. The following equations from Vollenweider's hydraulic model [31] were used to calculate phosphorus loads in the lakes:

$\mathrm{L}_{\text {perm }}(\mathrm{TP})=10 \mathrm{q}_{\mathrm{s}}\left(1+\mathrm{d}_{\text {mean }} / \mathrm{q}_{\mathrm{s}}\right)^{0,5}$

$\mathrm{L}_{\text {dang }}(\mathrm{TP})=20 \mathrm{q}_{\mathrm{s}}\left(1+\mathrm{d}_{\text {mean }} / \mathrm{q}_{\mathrm{s}}\right)^{0,5}$, where

$\mathrm{L}_{\text {perm }}(\mathrm{TP})$ - permissible load of phosphorus $\left(\mathrm{mg} \mathrm{P} \mathrm{m}^{-2}\right)$;

$\mathrm{L}_{\text {dang }}(\mathrm{TP})$ - dangerous load of phosphorus $\left(\mathrm{mg} \mathrm{P} \mathrm{m}^{-2}\right)$;

$\mathrm{q}_{\mathrm{s}}$ - hydraulic loading of the lake ( $\mathrm{m}$; product of the average depth of the lake and annual intensity of water exchange in the lake);

$\mathrm{d}_{\text {mean }}$-average lake depth (m);

10—spring phosphorus concentration in oligotrophic lakes; 20 - coefficient of the critical load for meso-eutrophic lakes [1].

Knowing the permissible, dangerous, and actual loads, three categories of lakes were established to show that the actual load entering the lake can cause an acceleration of eutrophication $[12,33,34]$ (Table 7).

Table 7. Lake hazard categories.

\begin{tabular}{cl}
\hline Load Level & Hazard Category \\
\hline $\mathrm{L}_{\text {actual }}<\mathrm{L}_{\text {perm }}$ & I-ensures that the existing state of eutrophication is maintained in the long term \\
$\mathrm{L}_{\text {perm }}<\mathrm{L}_{\text {actual }}<\mathrm{L}_{\text {dang }}$ & II—there is no guarantee of maintaining permanent mesotrophic conditions \\
$\mathrm{L}_{\text {actual }}>\mathrm{L}_{\text {dang }}$ & III-eutrophication is highly likely to progress rapidly \\
\hline
\end{tabular}

The internal load (from bottom sediments) was determined using the model by Uchmanski and Szeligiewicz [35]. 
$\mathrm{L}_{\text {total }}=\mathrm{TP} \mathrm{q}_{\mathrm{s}}\left(1+0.866(\mathrm{WE})^{0.5}\right)$, where

$\mathrm{L}_{\text {total }}$-annual phosphorus load from the catchment to the lake $\left(\mathrm{mg} \mathrm{P} \mathrm{m}^{-2}\right)$;

$\mathrm{TP}$-current concentration of total phosphorus in the lake water $\left(\mathrm{mg} \mathrm{P} \mathrm{m}^{-3}\right)$;

$\mathrm{q}_{\mathrm{s}}$-hydraulic loading of the lake $(\mathrm{m})$;

WE-number of water exchanges per year.

\subsection{Determination of the Trophic State of the Lakes}

In this paper, the actual trophic state was determined using the method adopted by the Organization for Economic Cooperation and Development (OECD), proposed by Vollenweider [32], which is based on measurements of oxygenation at the peak of summer, heterothermia of the bottom-layer waters, annual averages and maximum values of Secchi disk visibility (SD), and total phosphorus and chlorophyll "a" content in surface waters. The Carlson method [36], based on measurements in summer of surface water total phosphorus, chlorophyll "a", and Secchi disk visibility, is transformed into numerical indicators (lake trophy state indicators-TSI), which are a kind of a comparable "measure" of the level of eutrophication process. The description of these trophic assessment methods is presented in Tables 8 and 9. The actual trophic state, according to Carlson [36], is the average TSI, i.e., the average value of detailed indicators.

Table 8. Vollenweider indicators of trophic state [32].

\begin{tabular}{|c|c|c|c|c|c|c|}
\hline Trophic State & $\begin{array}{c}\mathrm{TP}_{\text {mean. }} \\
\text { (Average } \\
\text { Spring-Summer) }\end{array}$ & $\begin{array}{c}\mathrm{Chl}_{\mathrm{a}} \\
\text { (Summer) }\end{array}$ & $\begin{array}{c}\text { Chl } \\
\text { (Average } \\
\text { Spring-Summer) }\end{array}$ & $\begin{array}{c}\text { SD } \\
\text { (Summer) }\end{array}$ & $\begin{array}{c}\text { SD } \\
\text { (Average } \\
\text { Spring-Summer) }\end{array}$ & $\begin{array}{c}\% \mathrm{O}_{2} \\
\text { (Summer, at the } \\
\text { Lake Bottom) }\end{array}$ \\
\hline Units & $\left(\mathrm{mg} \mathrm{P} \cdot \mathrm{dm}^{-3}\right)$ & $\left(\mu \mathrm{g} \cdot \mathrm{m}^{-3}\right)$ & $\left(\mu \mathrm{g} \cdot \mathrm{m}^{-3}\right)$ & (m) & (m) & - \\
\hline Ultraoligotrophic & $\leq 0.004$ & $\leq 2.5$ & $\leq 1.0$ & $\geq 6.0$ & $\geq 12.0$ & $\geq 90.0$ \\
\hline Oligotrophic & $\leq 0.010$ & $\leq 8.0$ & $\leq 2.5$ & $\geq 3.0$ & $\geq 6.0$ & $\geq 80.0$ \\
\hline Mesotrophic & $\leq 0.035$ & $\leq 25$ & $\leq 8.0$ & $\geq 1.5$ & $\geq 3.0$ & $\geq 40.0$ \\
\hline Eutrophic & $\leq 0.100$ & $\leq 75$ & $\leq 25$ & $\geq 0.7$ & $\geq 1.5$ & $\geq 10.0$ \\
\hline Hypertrophic & $>0.100$ & $>75$ & $>25$ & $<0.7$ & $<1.5$ & $<10$ \\
\hline
\end{tabular}

Table 9. Carlson indicators of trophic state (TSI) [36].

\begin{tabular}{lccc}
\hline \multicolumn{1}{c}{ Trophic State } & $\begin{array}{c}\text { TSI-SD } \\
\text { (Summer) }\end{array}$ & $\begin{array}{c}\text { TSI-Chl } \\
\text { (Summer) }\end{array}$ & $\begin{array}{c}\text { TSI-TP } \\
\text { (Summer) }\end{array}$ \\
\hline Oligotrophic & $\leq 40$ & $\leq 40$ & $\leq 40$ \\
Mesotrophic & $\leq 60$ & $\leq 60$ & $\leq 60$ \\
Eutrophic & $61-80$ & $61-80$ & $61-80$ \\
Hypertrophic & $>80$ & $>80$ & $>80$ \\
\hline
\end{tabular}

Where:

$$
\begin{aligned}
& \mathrm{TSI}-\mathrm{SD}=10\left(6-\frac{\ln \mathrm{SD}}{\ln 2}\right) \\
& \mathrm{TSI}-\mathrm{SD}=10\left(6-\frac{\ln \mathrm{SD}}{\ln 2}\right) \\
& \mathrm{TSI}-\mathrm{TP}=10\left(6-\frac{\frac{\ln 48}{\mathrm{TP}}}{\ln 2}\right)
\end{aligned}
$$

\section{Results and Discussion}

The results of the performed water quality analyses of the examined lakes are summarized in Tables 10 and 11. During the study period, clear vertical patterns of physical and water quality parameters were observed. The surface layers of the studied lakes in the spring had a higher water temperature than the bottom layers, with the greatest temperature drop in the vertical system observed in Maszewo Lake at $9.4^{\circ} \mathrm{C}$ (Table 10). In the summer, higher temperatures were recorded in the bottom layers of the studied lakes than in the spring (Table 11). In the surface layers, a higher dissolved 
oxygen concentration was also found in both spring and summer (Tables 10 and 11). The bottom layers of the Maszewo and Starzyca lakes were characterized by almost complete deoxidation $(0.1$ and $0.2 \mathrm{mg} \mathrm{O}_{2} \mathrm{dm}^{-3}$ ) during the spring (Table 10). Concentrations of TP in surface and bottom layers in the lakes (both during spring and summer) exceeded the TP threshold for hypereutrophic systems (Table 11). In Lake Starzyca, chlorophyll "a" concentration in the surface layer in the summer indicated hypertrophy (Table 11). The results obtained indicate an intensive assimilation process in the surface layer, which results in an increase in the rate of dissimilation processes below the surface layer, leading to significant deoxidation of the bottom layers. Oxygen conditions in the bottom layers have contributed to an increase in the concentration of total phosphorus in these layers, which in turn indicates the recirculation of phosphorus from bottom sediments to the water column, thus contributing to so-called "secondary" eutrophication [37].

Table 10. Mean indicators in the analyzed lakes in spring.

\begin{tabular}{|c|c|c|c|c|c|}
\hline \multirow[t]{2}{*}{ Lake } & $\begin{array}{c}\text { Dissolved } \\
\text { Oxygen (DO) }\end{array}$ & Temperature & $\begin{array}{l}\text { Secchi Disc } \\
\text { (SD) }\end{array}$ & $\begin{array}{l}\text { Total Phosphorus } \\
\text { (TP) }\end{array}$ & Chlorophyll a \\
\hline & $\left(\mathrm{mg} \mathrm{O}_{2} \mathrm{dm}^{-3}\right)$ & $\left({ }^{\circ} \mathrm{C}\right)$ & (m) & $\left(\mathrm{mg} \mathrm{P} \mathrm{dm} \mathrm{m}^{-3}\right)$ & $\left(\mu \mathrm{g} \mathrm{dm}^{-3}\right)$ \\
\hline Maszewo surface & 17.1 & 20.7 & \multirow{2}{*}{1.1} & 0.126 & 43.0 \\
\hline Maszewo bottom & 0.2 & 11.3 & & 0.413 & 20.3 \\
\hline Starzyca surface & 11.6 & 21.2 & \multirow{2}{*}{1.5} & 0.153 & 30.0 \\
\hline Starzyca bottom & 0.1 & 12.0 & & 0.189 & 23.0 \\
\hline Nowogardzkie surface & 12.6 & 18.2 & \multirow{2}{*}{1.9} & 0.232 & 14.1 \\
\hline Nowogardzkie bottom & 1.1 & 12.3 & & 0.377 & 13.9 \\
\hline
\end{tabular}

Table 11. Mean indicators in the analyzed lakes in summer.

\begin{tabular}{|c|c|c|c|c|c|}
\hline \multirow[t]{2}{*}{ Lake } & $\begin{array}{c}\text { Dissolved } \\
\text { Oxygen (DO) }\end{array}$ & Temperature & $\begin{array}{l}\text { Secchi Disc } \\
\text { (SD) }\end{array}$ & $\begin{array}{l}\text { Total Phosphorus } \\
\text { (TP) }\end{array}$ & Chlorophyll a \\
\hline & $\left(\mathrm{mg} \mathrm{O}_{2} \mathrm{dm}^{-3}\right)$ & $\left({ }^{\circ} \mathrm{C}\right)$ & (m) & $\left(\mathrm{mg} \mathrm{P} \mathrm{dm}{ }^{-3}\right)$ & $\left(\mu \mathrm{g} \mathrm{dm}^{-3}\right)$ \\
\hline Maszewo surface & 8.2 & 20.3 & \multirow[b]{2}{*}{0.9} & 0.283 & 30.2 \\
\hline Maszewo bottom & 0.1 & 15.2 & & 0.686 & 24.6 \\
\hline Starzyca surface & 11.5 & 20.3 & \multirow{2}{*}{1.0} & 0.181 & 82.5 \\
\hline Starzyca bottom & 0.2 & 18.1 & & 0.619 & 17.1 \\
\hline Nowogardzkie surface & 9.3 & 19.7 & \multirow{2}{*}{1.2} & 0.234 & 21.6 \\
\hline Nowogardzkie bottom & 1.1 & 12.4 & & 1.261 & 14.7 \\
\hline
\end{tabular}

Assessment of the individual resilience characteristics of the lakes analyzed indicates that Maszewo Lake is a nonresilient lake that is strongly exposed to the influence from the catchment (Category IV); Starzyca Lake shows low resilience (Category III) and Nowogardzkie Lake shows moderate resilience (Category II)-Table 12.

Table 12. Individual resilience characteristics of the lakes under analysis.

\begin{tabular}{|c|c|c|c|c|c|c|c|c|c|c|c|}
\hline \multirow{3}{*}{ Lake } & \multicolumn{10}{|c|}{ Parameters According to Table 5} & \multirow{3}{*}{$\begin{array}{l}\text { Final } \\
\text { Score }\end{array}$} \\
\hline & \multicolumn{2}{|c|}{ (a) } & \multicolumn{2}{|c|}{ (b) } & \multicolumn{2}{|c|}{ (c) } & \multicolumn{2}{|c|}{ (d) } & \multicolumn{2}{|c|}{ (e) } & \\
\hline & $\mathbf{m}$ & pts & $\mathrm{m}^{3} \cdot \mathrm{m}^{-1}$ & pts & $\%$ & pts & $\mathrm{m}^{2} \cdot \mathrm{m}^{-3}$ & pts & $\mathrm{m}^{2} \cdot \mathrm{m}^{-3}$ & pts & \\
\hline Maszewo & 2.0 & 3 & 0.83 & 3 & 0 & 3 & 0.48 & 3 & 40.2 & 2 & 2.8 \\
\hline Starzyca & 2.6 & 3 & 2.94 & 2 & 0 & 3 & 0.38 & 3 & 15.6 & 1 & 2.4 \\
\hline Nowogardzkie & 5.1 & 1 & 3.15 & 1 & 2.3 & 3 & 0.18 & 2 & 1.4 & 0 & 1.4 \\
\hline
\end{tabular}

The anthropogenic pressure was assessed on the basis of estimation of the nutrient loads entering the lake. The load of phosphoric biogenic compounds entering the lake (actual load- $\mathrm{L}_{\text {act }}$ ) was estimated on the basis of the inflow from land and individual sources (Table 13). 
Table 13. Annual phosphorous load in the analyzed lakes from the surrounding land.

\begin{tabular}{|c|c|c|c|c|c|c|c|c|c|c|c|c|c|c|c|c|c|}
\hline \multirow{3}{*}{ Lake } & \multirow{2}{*}{\multicolumn{3}{|c|}{$\begin{array}{c}\text { Lake Surface } \\
\text { Phosphorous Load } \\
\left(0.5 \mathrm{~kg} \mathrm{P} \mathrm{ha}^{-1}\right)\end{array}$}} & \multirow{2}{*}{\multicolumn{3}{|c|}{$\begin{array}{c}\text { Arable Land } \\
\text { Phosphorous Load } \\
\left(0.4 \mathrm{~kg} \mathrm{P} \mathrm{ha}^{-1}\right)\end{array}$}} & \multirow{2}{*}{\multicolumn{3}{|c|}{$\begin{array}{c}\text { Forests } \\
\begin{array}{c}\text { Phosphorous Load } \\
\left(0.1 \mathrm{~kg} \mathrm{P} \mathrm{ha}^{-1}\right)\end{array}\end{array}$}} & \multirow{2}{*}{\multicolumn{3}{|c|}{$\begin{array}{c}\text { Urban Areas } \\
\text { Phosphorous Load } \\
\left(0.9 \mathrm{~kg} \mathrm{P} \mathrm{ha}^{-1}\right)\end{array}$}} & \multirow{2}{*}{\multicolumn{3}{|c|}{$\begin{array}{c}\text { Meadow } \\
\begin{array}{c}\text { Phosphorous Load } \\
\left(0.4 \text { kg P ha }^{-1}\right)\end{array}\end{array}$}} & \multirow{2}{*}{\multicolumn{2}{|c|}{$\begin{array}{c}\text { Total } \\
\text { Phosphorous } \\
\text { Load }\end{array}$}} \\
\hline & & & & & & & & & & & & & & & & & \\
\hline & ha & kg & $\begin{array}{l}\mathrm{g} \mathrm{m}^{-2} \\
\text { 'year }\end{array}$ & ha & kg & $\begin{array}{l}\mathrm{g} \mathrm{m}^{-2} \\
\text { 'year }\end{array}$ & ha & kg & $\begin{array}{l}\mathrm{g} \mathrm{m}^{-2} \\
\text { year }^{-1}\end{array}$ & ha & kg & $\begin{array}{l}\mathrm{g} \mathrm{m}^{-2} \\
\text {-year }\end{array}$ & ha & kg & $\begin{array}{l}\mathrm{g} \mathrm{m}^{-2} \\
\text { year }^{-1}\end{array}$ & kg & $\begin{array}{l}\mathrm{g} \mathrm{m}^{-2} \\
\text { year }^{-1}\end{array}$ \\
\hline Maszewo & 12.8 & 6.4 & 0.050 & 90.0 & 36.0 & 0.040 & 74.0 & 7.4 & 0.010 & 172.0 & 154.8 & 0.107 & 21.0 & 8.4 & 0.041 & 213.0 & 0.248 \\
\hline Starzyca & 59.2 & 29.5 & 0.050 & 83.0 & 33.2 & 0.044 & 35.7 & 3.6 & 0.009 & 34.0 & 30.6 & 0.090 & 17.0 & 6.8 & 0.040 & 103.7 & 0.233 \\
\hline Nowogardzkie & 98.3 & 49.2 & 0.050 & 322.8 & 129.1 & 0.066 & 107.6 & 10.8 & 0.013 & 145.6 & 131.0 & 0.096 & 57.0 & 22.8 & 0.052 & 342.9 & 0.277 \\
\hline
\end{tabular}


The estimated actual load was compared with the permissible and dangerous load, which allowed us to assess the category of the lakes. It was assumed that the permissible (critical) load ( $\mathrm{L}_{\text {perm }}$ ) is the maximum amount of phosphorus that, when introduced into a particular lake, does not cause permanent changes in the lake ecosystem [38]. On the other hand, a dangerous load $-\mathrm{L}_{\mathrm{dang}}-$ accelerates eutrophication and destabilizes the quality of the ecosystem.

Three categories of lakes were established to show that the actual load entering the lake causes an acceleration of eutrophication (Table 14). This method allows us to assess whether the phosphorus load from external sources is safe for the lake and whether it exceeds the permissible or dangerous loads. Table 14 presents the risk categories for the lakes under analysis and indicates the level of exceedance of acceptable and dangerous loads. Maszewo Lake was classified as category I. Although the assessment of particular resilience characteristics of this lake indicates that it is a nonresilient lake, strongly exposed to the influences from the catchment (Category IV), the high water exchange in the lake indicates that the trophic state could be preserved. The remaining lakes (Starzyca and Nowogardzkie) were classified as Category III, i.e., showing a high probability of rapid eutrophication.

Table 14. Hazard categories based on the estimated phosphorous loads (real, permissible, and dangerous).

\begin{tabular}{|c|c|c|c|c|c|c|}
\hline \multirow{3}{*}{ Lake } & \multicolumn{3}{|c|}{ Phosphorus Load } & \multirow{3}{*}{$\begin{array}{l}\text { The Permissible } \\
\text { Load Exceeded by: }\end{array}$} & \multirow{3}{*}{$\begin{array}{l}\text { The Dangerous } \\
\text { Load Exceeded by: }\end{array}$} & \multirow{3}{*}{$\begin{array}{l}\text { Hazard } \\
\text { Category }\end{array}$} \\
\hline & Real & Permissible & Dangerous & & & \\
\hline & $\mathrm{g} \cdot \mathrm{m}^{-2} \cdot$ year $^{-1}$ & $\mathrm{~g} \mathrm{~m}^{-2} \cdot$ year $^{-1}$ & $\mathrm{~g} \cdot \mathrm{m}^{-2} \cdot$ year $^{-1}$ & & & \\
\hline Starzyca & 0.233 & 0.074 & 0.149 & 3.1 & 1.6 & III \\
\hline Nowogardzkie & 0.277 & 0.065 & 0.130 & 4.3 & 2.1 & III \\
\hline
\end{tabular}

In both lakes, dangerous loads were exceeded (by 1.6 in Starzyca Lake and by 2.1 in Nowogardzkie Lake (Table 14).

The estimated actual phosphorus load was compared with the phosphorus load in the lake in order to assess the impact of the internal source. If the annual total phosphorus load is greater than the actual load, the influx of phosphorus to the lake is internal and external. If, on the other hand, the annual total phosphorus load is lower than the actual load, the influx of phosphorus to the lake is external (Table 15).

Table 15. Total and actual phosphorus loads reaching the lakes.

\begin{tabular}{|c|c|c|c|}
\hline \multirow{2}{*}{ Lake } & Actual Phosphorus Load & \multirow{2}{*}{ Relation } & Total Phosphorus Load \\
\hline & $\mathrm{g} \mathrm{m}^{-2} \cdot$ year $^{-1}$ & & $\mathrm{~g} \mathrm{~m}^{-2} \cdot$ year $^{-1}$ \\
\hline Maszewo & 0.248 & $<$ & 18.9 \\
\hline Starzyca & 0.233 & $<$ & 8.9 \\
\hline Nowogardzkie & 0.277 & $<$ & 7.6 \\
\hline
\end{tabular}

In all three lakes, phosphorus load is the result of external and internal supply, with the internal supply possibly playing a significant role, which is likely important in Maszewo Lake.

Different methods can be used to assess the trophic state of a lake. In this paper, the actual trophic state was determined on the basis of the method adopted by the Organization for Economic Cooperation and Development (OECD), proposed by Vollenweider [32]. Another method used in this work is the widely used Carlson method [36].

The assessment of the actual trophic state, according to Vollenweider (1989), is presented in Table 16 and, according to Carlson [36], in Table 17. From the calculations obtained, it was found that the Vollenweider [32] assessment of Nowogardzkie Lake for chlorophyll "a" qualifies the lake as mesotrophic. The remaining parameters qualify Nowogardzkie Lake as eutrophic and hypertrophic. 
Only two parameters indicated hypertrophication-mean total phosphorus concentration in spring and summer, and oxygenation of the bottom layer (Table 16).

Maszewo and Starzyca lakes are eutrophic-hypertrophic lakes, but Starzyca Lake shows eutrophic lake conditions only for one parameter (Secchi disk visibility). In turn, the assessment based on Carlson [36] indicates that all three lakes are eutrophic lakes (Table 17).

Although all the lakes examined are in poor ecological condition, they all differed in terms of possible methods of restoration. Maszewo Lake is a nonresilient lake, strongly exposed to influences from the catchment, but it does not exceed the permissible and dangerous phosphorus loads, mainly due to the low residence time. Unfortunately, although these loads are not exceeded, the dominant source of phosphorus is internal supply. It is a eutrophic lake, or-according to Vollenweider [32]-a eutrophic-hypertrophic lake.

Starzyca Lake, on the other hand, shows little resilience to the influence of the catchment, and unfortunately, the permissible and dangerous phosphorus loads have been exceeded. The supply of phosphorus to the lake's waters is a result of inflow from the catchment and internal supply. Starzyca Lake is also a eutrophic lake. Nowogardzkie Lake is characterized by the highest category of resilience to impacts from the catchment, although, unfortunately, it is only a medium resilience, which, when the permissible and dangerous phosphorus loads are exceeded, does not guarantee the proper functioning of this ecosystem. Nowogardzkie Lake is a eutrophic lake. Therefore, it should be stated that all three lakes have degraded resources. The fact that the lakes are situated in the town centers with a significant share of arable land in their catchment undoubtedly contributes to this condition.

Multidirectional analysis of the factors and causes of lake eutrophication may be the basis for developing specific corrective measures in the catchment and/or in the lake in order to halt the eutrophication process. Examples of such actions were presented by Bajkiewicz-Grabowska [1]. Based on the Maszewo, Starzyca, and Nowogardzkie lakes having low catchment resilience and being in a low-hazard category, as well as being highly eutrophic, it can be postulated that actions should be taken to reduce the anthropogenic pressure and to introduce reclamation measures within the lake basin (Table 18).

Maszewo, Starzyca and Nowogardzkie lakes have an established risk of not meeting environmental objectives over the last six years, and, unfortunately, this detailed analysis of the environmental conditions of these lakes strongly confirms it. Six years may be too short a period for the water conditions to improve, even if human pressure is completely eliminated. Pollutants accumulate in the lakes, mainly in bottom sediments, where they remain a source of biogenic compounds released to the lake waters over a very long time after the inflow of pollutants has stopped.

Nevertheless, a complete shut-off of the inflow of pollutants directly from the catchment to the lake waters is beneficial for the lakes and is a relatively low-cost treatment compared to typical reclamation treatments within the lake basin. This applies to pollutants introduced point-wise (e.g., by cutting off the sewage supply, construction of a band sewage system, three-stage wastewater treatment) in diffused pollution-related (liquidation of leaking septic tanks, sewerage of settlements and construction of local or collective wastewater treatment plants), atmospheric-related (changes in combustion technology and energy carriers, filters), and area-related (often identified with agricultural pollution) ways [12]. 
Table 16. Trophic state of the analyzed lakes, according to Vollenweider [32].

\begin{tabular}{|c|c|c|c|c|c|c|c|c|c|c|c|c|}
\hline Lake & $\begin{array}{l}\mathbf{T P}_{\text {mean }} \text { (Average } \\
\text { Spring-Summer) }\end{array}$ & $\begin{array}{l}\text { Trophic } \\
\text { State }\end{array}$ & $\begin{array}{c}\text { Chl }_{\mathrm{a}} \\
\text { (Summer) }\end{array}$ & $\begin{array}{l}\text { Trophic } \\
\text { State }\end{array}$ & $\begin{array}{c}\mathrm{Chl}_{\mathrm{a}} \\
\text { (Average for } \\
\text { Spring-Sumer) }\end{array}$ & $\begin{array}{l}\text { Trophic } \\
\text { State }\end{array}$ & $\begin{array}{c}\text { SD } \\
\text { (Summer) }\end{array}$ & $\begin{array}{l}\text { Trophic } \\
\text { State }\end{array}$ & $\begin{array}{c}\text { SD } \\
\text { (Average for } \\
\text { Spring-Summer) }\end{array}$ & $\begin{array}{l}\text { Trophic } \\
\text { state }\end{array}$ & $\begin{array}{c}\%^{\% \mathrm{O}_{2}} \\
\text { (Summer at the } \\
\text { Bottom) }\end{array}$ & $\begin{array}{c}\text { Trophic } \\
\text { State }\end{array}$ \\
\hline Maszewo & 0.377 & $\mathrm{H}$ & 57.7 & E & 50.4 & $\mathrm{H}$ & 0.9 & E & 1.0 & $\mathrm{H}$ & 1.7 & $\mathrm{H}$ \\
\hline Starzyca & 0.167 & $\mathrm{H}$ & 82.5 & $\mathrm{H}$ & 56.7 & $\mathrm{H}$ & 1.0 & E & 1.3 & $\mathrm{H}$ & 0.8 & $\mathrm{H}$ \\
\hline Nowogardzkie & 0.233 & $\mathrm{H}$ & 21.6 & M & 18.0 & E & 1.2 & E & 1.6 & $\mathrm{E}$ & 1.7 & $\mathrm{H}$ \\
\hline
\end{tabular}

H-hypertrophic, E-eutrophic, M-mesotrophic. 
Table 17. Trophic state of the analyzed lakes, according to Carlson [36].

\begin{tabular}{lccccc}
\hline \multirow{2}{*}{ Lake } & \multicolumn{4}{c}{ Carlson Indices } & \multirow{2}{*}{ Trophic State } \\
\cline { 2 - 5 } & TSI-SD & TSI-Chl & TSI-TP & TSI & \\
\hline Maszewo & 61.5 & 70.4 & 85.6 & 73.7 & eutrophic \\
Starzyca & 60.0 & 73.9 & 79.1 & 71.0 & eutrophic \\
Nowogardzkie & 57.4 & 60.7 & 82.5 & 66.9 & eutrophic \\
\hline
\end{tabular}

Table 18. A summary of the indicators used to assess the anthropogenic pressure to Maszewo, Starzyca, and Nowogardzkie lakes.

\begin{tabular}{lcclc}
\hline Lake & $\begin{array}{c}\text { Category of Resilience } \\
\text { to the Influence of the } \\
\text { Catchment }\end{array}$ & Hazard Category & $\begin{array}{l}\text { The Way of Phosphorus } \\
\text { Supply to the Lake }\end{array}$ & $\begin{array}{c}\text { Trophic State } \\
\text { according to } \\
\text { Carlson [36] }\end{array}$ \\
\hline Maszewo & IV & I & $\begin{array}{l}\text { from the catchment and } \\
\text { externally } \\
\text { from the catchment and } \\
\text { externally } \\
\text { from the catchment and } \\
\text { externally }\end{array}$ & eutrophic \\
Starzyca & III & III & eutrophic \\
Nowogardzkie & II & III & eutrophic \\
\hline
\end{tabular}

It is precisely by cutting off the inflow of pollutants that the water quality may improve relatively quickly. In Lake Washington, after the cutoff of sewage inflow at the end of the 1960s, it took only several years for the phosphorus concentration to return to levels recorded in the 1930s. According to Kajak [39], such a good result can only be achieved in a relatively clean lake. The state of the Washington Lake at the time of taking radical protective measures was between mesotrophic and eutrophic.

As a result of the interruption of the sewage inflow, the concentration of nutrients in the lake water decreases, but remains high enough to cause algal blooms for a long time. This is confirmed by activities carried out in Poland to reduce the inflow of pollutants to lakes (numerous proecological investments, modernization of sewage treatment plants), which resulted in a significant reduction of phosphorus concentration in the lakes by the end of the 1990s, but did not bring a simultaneous significant reduction of chlorophyll content [40].

The reclamation techniques currently in use generally fall into three categories:

- technical: removal of water from the hypolimnion, aeration of surface water, rinsing [41-43];

- chemical: phosphorus inactivation, biochemical oxygenation of bottom sediments, application of preparations against cyanobacteria [44-46];

- biological: control of ichthyofauna structure, removal of bioseston, cultivation of macrophytes, introduction of biofiltering bivalve molluscs, introduction of effective microorganisms [47-49].

Only a reduction in anthropogenic pressure, in combination with various reclamation treatments, can stop the eutrophication process and improve the ecological condition. However, such treatments require time and are relatively costly. Permazzi et al. [50] estimate the time needed to reach a target state for Lake Varese (Italy, Lombardy) at 25-30 years. Another example of the importance of the length of time is the introduction of good agricultural practices in the American Lake Okeechobee (Florida) catchment, which resulted in improved water quality after about 10 years [51].

In Poland, reclamation activities have been conducted since the mid-20th century. For example, Kortowskie Lake has been under reclamation since 1956, another two lakes have been under reclamation since the 1970s. In 1970s Długie Lake was reclaimed, and reclamation of another 17 lakes began in the 1980s. The effectiveness of those measure have proved rather unsatisfactory (apart from Kortowskie Lake, where a significant improvement in water quality was achieved-Lossow [12]) mainly due to a failure to meet the basic requirement of cutting off the inflow of pollutants from the land and individual sources. The high efficiency of the Długie Lake reclamation was achieved using two methods-artificial aeration with thermal destratification and inactivation using hydrolyzed polyaluminium chloride [52]. 
Phosphorus inactivation is a method that has been applied to treat eutrophic lakes. The method includes precipitation of phosphorus with coagulants and subsequent inactivation in the sediments. As coagulants, iron salts, calcium and mainly aluminium sulfate were used. Aluminium hydroxide flocs cover bottom sediments and further phosphorus sorption occurs even under anaerobic conditions. The first application of the method took place in Lake Longsjon in Sweden [53]. The coagulant was added in solid or liquid form to the surface of the water (sometimes ice) or directly to hypolimnion. As a rule, a clearly marked reduction in the amount of phosphorus in the water and a reduction in lake trophy are obtained [12]. Phosphorus precipitation is only possible on small tanks; it does not guarantee the permanent removal of phosphorus from the water column, especially in reservoirs where sediments over the whole or a significant area may be resuspended under wave action. Sometimes it is combined with aeration [12].

Two of the lakes analyzed in this study, Starzyca and Nowogardzkie, are being reclaimed using aeration and the use of PIX coagulants (iron coagulant IC - water solution of ferric chloride $\left[\mathrm{FeCl}_{3}\right]$ ), combined methods of reclamation, where very good effects should be expected in hydrochemical conditions [43]. In Starzyca Lake, an aerator was installed in April 2003, as well as in Nowogardzkie Lake in 2014 [54]. In Starzyca Lake, studies were carried out in 2008-2010, and in Nowogardzkie Lake in 2015. In both lakes, installation of the aerators resulted in a decrease of $\mathrm{DO} \%$ in the summer season [54]. The very important role of bottom sediments should be considered here, the mineralization of which contributes to a very fast oxygen consumption, which in consequence leads to activation of the internal phosphorus supply. The use of coagulants has not brought the expected results either, most probably due to hypoxia of the bottom layer. It cannot be expected that in these highly eutrophic lakes, such as Maszewo, Starzyca and Nowogardzkie lakes, a satisfactory reaction will take place in a short time.

Taking into account the observed low effectiveness of the reclamation measures carried out so far in Starzyca and Nowogardzkie lakes, cutting off the inflow of pollutants from the catchment should be accompanied by more radical actions (also for Maszewo Lake where no reclamation has been implemented so far). For example, a very radical but highly effective reclamation method is the removal of bottom sediments [55]. However, this method is relatively rarely used due to a number of reasons, primarily the high costs of sludge disposal $[48,56]$.

In this situation, the method proposed by Grochowska et al. [52], consisting of the use of a combined technology in which bottom sediment removal is combined with phosphorus inactivation, as well as biomanipulation, seems very promising. In this method, sludge is removed by means of a wormwheel gear refill device. The excavated material is stored in special fields where it can be used, for example, for agricultural purposes after a suitable composting time. However, such reclamation requires detailed research into the chemical and microbiological composition of the water and sludge so that after composting, the sludge can be used for agricultural purposes. Nonetheless, the authors declare that this method is three times cheaper than the traditional method of removing bottom sediments.

\section{Conclusions}

The studied Maszewo, Starzyca, and Nowogardzkie lakes are degraded ecosystems. Maszewo Lake is a nonresilient lake, strongly exposed to the influence from the catchment (Category IV), Starzyca Lake shows low resilience (Category III) and Nowogardzkie Lake shows moderate resilience (Category II). In all three lakes, the phosphorus load is the result of external and internal supply, with internal supply playing a significant role, which is particularly significant in the case of Maszewo Lake. Maszewo, Starzyca, and Nowogardzkie lakes are highly eutrophic.

This does not change the fact that they play a very important role in the local ecosystems, and in times of global climate change, no water resources can be neglected. Therefore, reclamation measures should be continued on Starzyca and Nowogardzkie lakes. On the other hand, on Maszewo Lake, protective measures should be introduced as soon as possible within the lake catchment area. 
Author Contributions: A.Z. conceived and designed the paper, partly analyzed the data, and wrote the paper; M.B. made chemical analyses and partly analyzed the data; A.R. made chemical analyses and partly analyzed the data; A.N. conceived and designed the research, and partly analyzed the data; A.T. collected samples from lakes. All authors have read and agreed to the published version of the manuscript.

Funding: This research received no external funding.

Conflicts of Interest: The authors declare no conflict of interest.

\section{References}

1. Bajkiewicz-Grabowska, E. Clear lakes. Diagn. Limnol. Res. 2010, 7, 74.

2. Vadeboncoeur, Y.M.; McIntyre, P.B.; Zanden, M.J.V. Borders of Biodiversity: Life at the Edge of the World's Large Lakes. BioScience 2011, 61, 526-537. [CrossRef]

3. Okuda, N.; Watanabe, K.; Fukumori, K.; Nakano, S.-I.; Nakazawa, T. Biodiversity in Aquatic Systems and Environments; Springer Science and Business Media: Berlin/Heidelberg, Germany, 2014.

4. Van Vuuren, D.P.; Bouwman, A.F.; Beusen, A.H.W. Phosphorus demand forthe 1970-2100 period: A scenario analysis of resource depletion. Glob. Environ. Chang. 2010, 20, 438-439. [CrossRef]

5. EEA, European Environment. State and Outlook. Part A-Integrated Assessment; European Environment Agency: Copenhagen, Danmark, 2005. (In Polish)

6. GUS, Environmental Protection. Statistical yearbook; Central Statistical Office: Warsaw, Poland, 2017. (In Polish)

7. Schindler, D.W. Eutrophication and Recovery in Experimental Lakes: Implications for Lake Management. Science 1974, 184, 897-899. [CrossRef] [PubMed]

8. Correll, D.L. Phosphorus: A rate limiting nutrient in surface waters. Poult. Sci. 1999, 78, 674-682. [CrossRef] [PubMed]

9. Yang, X.; Wu, X.; Hao, H.-L.; He, Z.-L. Mechanisms and assessment of water eutrophication*. J. Zhejiang Univ. Sci. B 2008, 9, 197-209. [CrossRef]

10. Taylor, W.; Lean, D.R.S. Observations on the dynamics and fate of dissolved organic phosphorus in lake water and a new model of eplimnetic P cycling. Aquat. Sci. 2018, 80, 13. [CrossRef]

11. Hillbricht-Ilkowska, A. Biodiversity of freshwater habitats-Problems, needs, activities. IDEE Ekol. Ser. Szkice $1989,13,13-55$.

12. Lossow, K. Lake protection and remediation-Theory and practice. IDEE Ekol. Ser. Szkice 1998, 13, 55-71.

13. Grochowska, J.; Tandyrak, R.; Augustyniak, R.; Łopata, M.; Parszuto, K. Nutrient Balance of North-Eastern Poland Lakes. In Polish River Basins and Lakes-Part I; Korzeniewska, E., Harnisz, M., Eds.; Springer: Berlin/Heidelberg, Germany, 2020; Volume 86.

14. Kowalczewska-Madura, K.; Dondajewska, R.; Gołdyn, R. Internal Phosphorus Loading in Eutrophic Lakes in Western Poland. In Polish River Basins and Lakes_Part I; Korzeniewska, E., Harnisz, M., Eds.; Springer: Berlin/Heidelberg, Germany, 2020; Volume 86. [CrossRef]

15. Kubiak, J. The largest dimictic lakes of West Pomerania. Trophy level, susceptibility on degradation and habitat conditions of ichthyofauna. Hear. AR Szczec. 2003, 214, 1-92. (In Polish)

16. Kubiak, J.; Tórz, A. Eutrophication basic problems of lake water protection in West Pomerania. Pole. Pr. Biol. 2005, 2, 17-36. (In Polish)

17. Wang, C.; Bi, J.; Fath, B.D. Effects of abiotic factors on ecosystem health of Taihu Lake, China based on eco-exergy theory. Sci. Rep. 2017, 7, 42872. [CrossRef] [PubMed]

18. Smith, V.H.; Schindler, D.W. Eutrophication science: Where do we go from here? Trends Ecol. Evol. 2009, 24, 201-207. [CrossRef] [PubMed]

19. Pathak, H. Eutrophication: Impact of Excess Nutrient Status in Lake Water Ecosystem. J. Environ. Anal. Toxicol. 2012, 2, 1-5. [CrossRef]

20. Xu, F.-L.; Tao, S.; Dawson, R.; Li, B.-G. A GIS-based method of lake eutrophication assessment. Ecol. Model. 2001, 144, 231-244. [CrossRef]

21. Hobot, A. (Ed.) Updating the List of JCWP and SCWP for the Purposes of the Next Update of Plans in 2015-2021 Together with Verification of Water Types of Water Bodies-STAGE I-Methodology; KZGW: Gliwice, Warszawa, Poland, 2014.

22. Illies, J. Limnofauna Europaea. 2. Aufl; G.Fischer-Verlag: Stuttgart, Germany, 1978. 
23. Kondracki, J. Regional Geography of Poland; PWN: Warszawa, Poland, 1998.

24. American Public Health Association (APHA). Standard Methods for Examination of Water and Wastewater, 21th ed.; American Public Health Association (APHA): Washington, DC, USA, 2005.

25. Kudelska, D.; Cydzik, D.; Soszka, H. Proposal of a lake quality assessment system. Wiad. Ekol. 1981, 27, 149-173.

26. Bajkiewicz-Grabowska, E. Assessment of the lakes susceptibility to degradation and the role of the catchment in this process. Wiad. Ekol. 1987, 33, 279-289.

27. Bajkiewicz-Grabowska, E. The degree of natural susceptibility of lakes to eutrophication on the example of selected Polish lakes. Gospod. Wod. 1990, 12, 270-272.

28. Bajkiewicz-Grabowska, E. Circulation of matter in river-lake systems; WGiSP UW: Warszawa, Poland, 2002.

29. Vollenweider, R.A. Scientific Fundamentals of the Eutrophication of Lakes and Following Waters, with Particular Reference to Nitrogen and Phosphorous as Factors in Eutrophication; Organisation for Economic Co-operation and Development: Paris, France, 1971; Volume 27, pp. 1-61.

30. Vollenweider, R.A. Input-output models with special reference to the phosphorus loading concept in limnolgy. Schweiz. Z. Hydrol. 1975, 37, 53-84.

31. Vollenweider, R.A. Advances in defining critical loading level for phosphorus in lake eutrophication. Mem. Inst. Ital. Hydrobiol. 1976, 33, 53-83.

32. Vollenweider, R.A. Global problems of eutrophication and its control. Symp. Biol. Hung. 1989, 38, $19-41$.

33. Hillbricht-Ilkowska, A.; Wisniewski, R. Trophic diversity of lakes of the Suwałki Landscape Park and its buffer zone-Current status, long-term variability, place in the trophic classification of lakes. In The Lake of the Suwatki Landscape Park. Relations with the Landscape, the State of Eutrophication and Protection Directions; Hillbricht-Ilkowska, A., Wiśniewski, R.J., Eds.; Scientific Publications of the Polish Academy of Science, Committee Human and Environment: Warszawa, Poland, 1994; Volume 7, pp. 181-200.

34. Hillbricht-Ilkowska, A.; Kostrzewska-Szalkowska, I. Assessment of the phosphorus load and threat status of the lakes of the Krutynia River (Masurian Lake District) and the relationship between the load and the phosphorus concentration in the lakes. In Operation of River and Lake Systems in the Lake Landscape: The Krutynia River (Masurian Lake District); Hillbricht-Ilkowska, A., Wisniewski, R.J., Eds.; Scientific Publications of the Polish Academy of Science, Committee Human and Environment: Warszawa, Poland, 1996; Volume 13, pp. 97-123.

35. Uchmański, J.; Szeligiewicz, W. Empirical models for predicting water quality, as applied to data on lakes of Poland. Ekol. Pol. 1989, 36, 285-316.

36. Carlson, R.E. A trophic state index for lakes. Limnol. Oceanogr. 1977, 22, 361-369. [CrossRef]

37. Wetzel, R.G. Limnology, Lake and River Ecosystems, 3rd ed.; Elsevier: Amsterdam, The Netherlands, 2001.

38. Hilbricht-Ilkowska, A. Ecological basis for surface water quality management and their habitat and nature. In Utilization and Protection of Surface Water Resources in Poland; Starkel, L., Ed.; Scientific Publications of the Polish Academy of Science, Committee Human and Environment: Warszawa Poland, 1997; Volume 17, pp. 63-88.

39. Kajak, Z. Dependences of chosen indices of structure and functioning of ecosystems of different trophic status and mictic type for 42 lakes. Ecological characteristics of lakes in northeastern Poland versus their trophic gradient. Ekol. Pol. 1983, 31, 495-530.

40. Cydzik, D.; Soszka, H. Changes in water quality of Polish lakes in the years 1991-2000 (based on lake monitoring results). Limnol. Rev. 2003, 3, 53-58.

41. Gawrońska, H.; Brzozowska, R.; Grochowska, J.; Lossow, K. Possibilities to reduce loading to lake water by artificial aeration. Pol. J. Environ. Stud. 2003, 12, 1710179.

42. Premazzi, G.; Cardoso, A.C.; Rodari, E.; Austoni, M.; Chiaudani, G. Hypolimnetic withdrawal coupled with oxygenation as lake restoration measures: The successful case of Lake Varese (Italy). Limnetica 2005, 24, 123-131.

43. Siwek, H.; Włodarczyk, M.; Czerniawski, R. Trophic State and Oxygen Conditions of Waters Aerated with Pulverising Aerator: The Results from Seven Lakes in Poland. Water 2018, 10, 219. [CrossRef]

44. Haghseresht, F.; Wang, S.; Do, D. A novel lanthanum-modified bentonite, Phoslock, for phosphate removal from wastewaters. Appl. Clay Sci. 2009, 46, 369-375. [CrossRef] 
45. Grochowska, J.; Brzozowska, R.; Łopata, M.; Augustyniak, R. Durability of changes in phosphorus compounds in water of an urban lake after application of two reclamation methods. Water Sci. Technol. 2013, 68, 234-239. [CrossRef]

46. Bonisławska, M.; Nęzarek, A.; Rybczyk, A. Assessment of the use of precipitating agents and ceramic membranes for treatment of effluents with high concentrations of nitrogen and phosphorus from recirculating aquaculture systems. Aquac. Res. 2019, 50, 1248-1256. [CrossRef]

47. Drenner, R.W.; Hambright, K.D. Review: Biomanipulation of fish assemblages as a lake restoration technique. Arch. Hydrobiol. 1999, 146, 129-165. [CrossRef]

48. Klapper, H. Technologies for lake restoration. J. Limnol. 2003, 62, 73. [CrossRef]

49. Sender, J.; Jaruga, C. Eutrophication of water reservoirs and role of macrophytes in this process. Inż. Ekol. 2017, 18, 228-245. [CrossRef]

50. Premazzi, G.; Dalmiglio, A.; Cardoso, A.C.; Chiaudani, G. Lake management in Italy: The implications of the Water Framework Directive. Lakes Reserv. Res. Manag. 2003, 8, 41-59. [CrossRef]

51. Daroub, S.H.; Lang, T.A.; Diaz, O.A.; Grunwald, S. Long-term water quality trends after imlementing best management practices in south Florida. J. Environ. Qual. 2009, 38, 1683-1693. [CrossRef]

52. Grochowska, J.; Łopata, M.; Augustyniak, R.; Płachta, A.; Tandyrak, R.; Parszuto, K. The innovative complex lake restoration technique designed for heavily polluted urban lake. Environ. Monit. Assess. 2020, in press.

53. Jernelov, A. Phosphate reduction in lakes by precipitation with aluminium sulphate. In Proceedings of the 5th International Water Pollution Research Conference, Lisbon, Portugal, 18-20 October 2020.

54. Wesołowski, P.; Brysiewicz, A. The effect of pulverising aeration on changes in the oxygen and nitrogen concentrations in water of Lake Starzyc. J. Water Land Dev. 2015, 25, 31-36. [CrossRef]

55. Rosińska, J.; Kozak, A.; Dondajewska-Pielka, R.; Kowalczewska-Madura, K.; Gołdyn, R. Water quality response to sustainable restoration measures-Case study of urban Swarzędzkie Lake. Ecol. Indic. 2018, 84, 437-449. [CrossRef]

56. Zamparas, M.; Zacharias, I. Restoration of eutrophic freshwater by managing internal nutrient loads. A review. Sci. Total. Environ. 2014, 496, 551-562. [CrossRef] 